\title{
PERBEDAAN MOTIVASI BELAJAR SISWA YANG MENDAPATKAN TEACHER CENTERED LEARNING (TCL) DENGAN STUDENT CENTERED LEARNING (SCL)
}

\author{
Rahila Salay \\ Program Studi Pendidikan Bahasa dan Sastra Indonesia \\ Fakultas Sastra, Universitas Muslim Indonesia \\ Email: rahilasalay97@gmail.com
}

\begin{abstract}
Abstrak: UU Nomor 20 Tahun 2003 tentang Sistem Pendidikan Nasional dan UU Nomor 12 Tahun 2012 tentang Pendidikan Tinggi dinyatakan bahwa pembelajaran adalah interaksi antara pendidik, peserta didik, dan sumber belajar di dalam lingkungan belajar tertentu. Dengan demikian, pengembangan kurikulum pembelajaran disusun berdasarkan pada elemen-elemen kompetensi yang dapat mengantarkan peserta didik untuk mencapai kompetensi lainnya yang diharapkan melalui metode-metode pembelajaran. Metode pembelajaran yang menumbuhkan hasrat besar untuk ingin tahu, meningkatkan kemampuan untuk menggunakan atribut kompetensi, guna menentukan pilihan, jalan berkehidupan di masyarakat, meningkatkan cara belajar sepanjang hayat. Student Centered Learning (SCL) adalah pola pembelajaran yang sangat cocok digunakan dalam (KBK) karena pada pola ini, pembelajaran berpusat pada siswa, sehingga untuk mencapai hasil pembelajaran tersebut, siswa harus melalui proses pembelajaran yang mengutamakan pengembangan kreativitas, kapasitas, kepribadian dan kebutuhannya serta mengembangkan kemandirian dalam mencari dan menemukan pengetahuan. Namun, tidak sedikit kita jumpai guru masih tetap menjadi sentral atau masih pada pola TCL (Teacher Centered Learning) di mana pengetahuan dipandang sebagai sesuatu yang sudah jadi, yang tinggal ditransformasi dari guru ke siswa sehingga siswa pasif dalam menerima pembelajaran di kelas. Paradigma seperti ini harus diubah, karena tantangan dunia pendidikan pada era globalisasi adalah menghasilkan Sumber Daya Manusia (SDM) yang mampu berperan secara global. Oleh karena itu, siswa sebaiknya dilatih sejak awal secara aktif belajar secara mandiri.
\end{abstract}

Kata kunci: Motivasi belajar, pembelajaran, TCL, SCL

\section{PENDAHULUAN}

Manusia merupakan ciptaan Tuhan yang paling sempurna karena dibekali dengan akal, pikiran dan perasaan. Manusia diberikan kemampuan untuk mengembangkan pendidikan dan pengetahuan sesuai dengan kemampuan yang dimilikinya secara terarah dan terpadu. Hal ini sesuai dengan Undangundang Nomor 20 tahun 2003 tentang sistem Pendidikan Nasional di Indonesia yaitu: pendidikan adalah usaha sadar dan terencana untuk mewujudkan suasana belajar dan proses pembelajaran agar peserta didik secara aktif mengembangkan potensi dirinya untuk memiliki kekuatan spiritual, keagamaan, pengendalian diri, kepribadian, kecerdasan, akhlak mulia, serta keterampilan yang diperlukan dirinya, masyarakat, bangsa dan negara (UU Sisdiknas, 2008:2).

Terkait hal di atas, untuk mewujudkan suatu tujuan dan menciptakan suasana yang lebih baik, maka perlu adanya motivasi dari segala arah. Sebab, seperti yang diketahui bahwa motivasi adalah dorongan dari diri sendiri atau orang lain yang dapat membuat seseorang melakukan sesuatu, atau membuat seseorang selangkah 
lebih maju menuju perubahan dari yang negatif ke positif. Hamalik (2012:173) mengemukakan bahwa istilah motivasi menunjuk kepada semua gejalah yang terkandung dalam stimulasi tindakan kearah tujuan tertentu dimana sebelumnya tidak ada gerakan menuju kearah tujuan tersebut. Motivasi dapat berupa dorongan -dorongan dasar atau internal dan intensif diluar diri individu atau hadiah sebagai suatu masalah di dalam kelas.

Motivasi memiliki kaitan yang sangat erat dengan belajar. Demikian, karena kelas akan kondusif apabila seluruh siswa turut berpartisipasi dalam proses pembelajaran. Untuk memperoleh suasana kelas demikian, perlu adanya motivasi yang lahir di lingkungan kelas (ekstrinsik) maupun dalam diri siswa tersebut (intrinsik). Terkhusus pada motivasi dari luar yang dibawa oleh pendidik. Motivasi ekstrinsik adalah motivasi yang dapat diperoleh dari lingkungan sekitar, sedangkan motivasi intrinsik adalah kebalikan dari motivasi ekstrinsik, di mana motivasi didapat dari dalam diri seseorang.

Motivasi memiliki ragam jenis, baik berupa materi maupun hanya sekadar katakata pendorong. Pada lingkup pendidikan, motivasi yang umum digunakan oleh pendidik adalah motivasi berupa materi, di mana guru dengan segala kekreativitasannya menggunakan berbagai strategi untuk mencapai tujuan dari kurikulum. Dalam hal ini, yang menjadi poin penting kegiatan pendidik selanjutnya adalah memilih pola atau model pembelajaran sesuai dengan kebutuhan siswa atau pola pembelajaran yang memungkinkan siswa turut aktif berpartisipasi dalam proses pembelajaran. Dalam dunia pendidikan, ada dua macam pola pembelajaran yang dikenal, yakni pola pembelajaran Teacher Centered Learning (TCL) dan Student Centered Learning (SCL).

TCL dan SCL adalah dua pola pembelajaran yang berbanding terbalik. Saat di mana TCL lebih berpusat kepada pendidik, maka SCL lebih menekankan pada keaktifan siswa dalam kelas. Di dalam setting TCL, motivasi siswa dalam belajar lebih banyak ekstrinsik karena bertumpu pada reward dan punishment yang diberikan oleh guru. Keadaan yang berbeda dijumpai pada kelas SCL di mana siswa didorong untuk belajar secara mandiri, bekerja dan belajar untuk menemukan banyak ide-ide, pengetahuan serta keterampilan baru berdasarkan motivasi intrinsik.

Berdasarkan beberapa uraian di atas, pentingnya sebuah pola pembelajaran dalam kelas menjadi sebuah kewajiban oleh pendidik. Namun, pada dewasa ini penggunaan pola pembelajaran seringkali dikesampingkan oleh pendidik. Pemilihan pola pembelajaran yang terkadang tidak sesuai dengan kebutuhan siswa sehingga mampu menjadi penghambat proses penerimaan. Kesulitan seperti ini bukan hal yang baru lagi di lingkup para pendidik. Sebab, di dalam suatu kelas ada puluhan kepala yang berbeda pemikiran dan berbeda pula kebutuhannya. Jadi, pendidik yang kurang kreatif, akan kewalahan apabila tidak terlalu menguasai teori tentang pola pembalajaran yang memiliki banyak bagian. Permasalan serupa juga terjadi di mana pendidik memilih metode pembelajaran yang tidak relevan dengan standar kompetensi yang akan dicapai.

$$
\text { Pentingnya sebuah pola }
$$
pembelajaran, menuntut guru menjadi lebih kreatif dan berwawasan luas. Sebab, siswa adalah makhluk yang sosial yang memiliki 
perbedaan yang sangat kental. Perbedaan yang dimaksud yakni, perbedaan individual anak didik pada aspek biologis, intelektual dan psikologis, mempengaruhi pemilihan dan penentuan metode yang mana guru sebaiknya ambil untuk menciptakan lingkungan belajar yang kreatif dalam waktu yang relative lama demi tercapainya tujuan pengajaran yang telah dirumuskan secara operasional.

\section{PEMBAHASAN}

\section{Motivasi Belajar}

Setiap aktivitas manusia pada dasarnya dilandasi oleh adanya dorongan untuk mencaai tujuan atau terpenuhinya kebutuhannya. Adanya daya pendorong ini disebut motivasi. Dalam beberapa terminolgi, motivasi dinyatakan sebagai suatu kebutuhan (needs), keinginan (wants), gerak hati (impulse), naluri (instincts) dan dorongan (drive), yaitu sesuatu yang memaksa organisme manusia untuk berbuat atau bertindak.

Motivasi adalah sebuah konsep yang digunakan untuk menjelaskan inisiasi, arah intensitas perilaku individu. Motivasi merupakan kekuatan yang mendorong seseorang melakukan sesuatu untuk mencapai tujuan, kekuatan ini diransang oleh adanya berbagai macam kebutuhan, seperti (1) keinginan yang hendak dipenuhi, (2) tingkah laku, (3) tujuan, (4) umpan balik (Hellriegel dan Slocum, 1979). Sebenarnya, dalam konsep motivasi terkandung tiga konsep penting , yaitu: (1) tujuan, (2) pengetahuan, proses-proses metakognitif (Byners, 1996). Tujuan merupakan spesifikasi yang berorientasi masa depan tentang apa yang diinginkan seseorang, sedangkan pengetahuan berkaitan dengan mengetahui tentang bagaimana membuat tujuan tercapai.
Proses-proses metakognitif mencakup memonitor kemajuan yang dicapai, menggunakan keyakinan dan pilihan untuk menilai tindakan yang berlangsung, menilai keinginan terhadap hasil, dan menjelaskan mengapa diperoleh hasil.

Petri (1981) menggambarkan motivasi sebagai kekuatan yang bertindak pada organisme yang mendorong dan mengarahkan perilakunya. Konsep motivasi juga digunakan untuk menjelaskan perbedaan-perbedaan dalam intensitas perilaku. Mc Donald mengatakan bahwa motivasi adalah sesuatu perubahan energy di dalam diri seseorang yang ditandai dengan timbulnya afektif (perasaan) dan reaksi untuk mencapai tujuan (Hamalik, 1992). Senada dengan hal tersebut Morgan dkk. (1986) mendefinisikan motivasi sebagai kekuatan yang menggerakan dan mendorong terjadinya perilaku yang diarahkan pada tujuan tertentu. Eggen dan Kauchak (1997) mendefiniskan motivasi sebagaii kekuatan yang memberi energy, menjaga kelangsungannya, dan mengarahkan perilaku terhadap tujuan. Jadi motivasi adalah suatu pendorong yang mengubah energy dalam diri seseorang ke dalam bentuk aktivitas nyata untuk mencapai tujuan tertentu. Dengan kata lain, motivasi adalah kondisi psikologis yang mendorong seseorang untuk melakukan sesuatu. Sedangkan Belajar merupakan suatu proses yang berlangsung sepanjang hayat. Hampir semua kecakapan, keterampilan, pengetahuan, kebiasaan, kegemaran dan sikap manusia terbentuk, dimodifikasikan dan berkembang karena belajar. Menurut Lester D. Crow (1958) menyatakan belajar adalah perolehan kebiasaan, pengetahuan, dan sikap termasuk cara baru untuk melakukan sesuatu dan upaya-upaya seseorang dalam mengatasi 
kendala atau menyesuaikan situasi yang baru. Cronbach (1960), dalam bukunya yang berjudul Educational Psykology menyatakan bahwa learning is shown by a change in behavior as a result of experience (belajar ditunjukkan oleh perubahan perilaku sebagai hasil pengalman). Definisi ini lebih menekankan pada perubahan, akan tetapi dijelaskan juga bahwa perubahan yang dimaksud adalah peubahan perilaku. Sehinnga dapat disimpulan bahwa belajar adalah sebuah proses yang memungkinkan seseorang memperoleh dan membentuk kompetensi, keterampilan dan sikap yang baru dalam melibatkan proses-proses mental internal yang terjadi berdasarkan latihan, pengalaman, dan interaksi sosial sehingga terjadinya perubahan perilaku baik actual maupun potensial. Jadi motivasi belajar adalah kondisi psikologis yang mendorong sesorang untuk belajar.

Dilihat dari sumbernya, motivasi belajar ada dua jenis, yaitu motivasi intrinsic dan motivasi ekstrinsik (Winkel, 1996). Motivasi intrinsik adalah motivasi yang timbul dari dalam diri orang yang bersangkutan tanpa rangsangan atau bantuan orang lain. Sesorang yang secara intrinsic termotivasi akan melakukan pekerjaan karena mendapatkan pekerjaan itu menyenagkan dan bisa memenuhi kebutuhannya, tidak tergantung ppada penghargaan-penghargaan eksplisit atau paksaan eksternal lainnya. Misalnya, seoarang siswa belajar dengan giat karena ingin menguasai berbagai ilmu yang dipelajari di sekolahnya. Motivasi intrinsic dapat berupa kepribadian, sikap, pengalaman, pendidikan, atau berupa penghargaan dan cita-cita. Motivasi ekstrinsik adalah motivasi yang timbul karena rangsangan atau bantuan dari orang lain. Motivasi ekstrinsik disebabkan oleh keinginan untuk menerima ganjaran ata menhindari hukuman, motivasi yang terbentuk oleh factor-faktor eksternal seperti ganjaran dan hukuman (Woolfolk, 1993). Misalnya seoarang siswa mengerjakan PR karena takut dihukum oleh gurunya.

\section{Pola Pembelajaran}

Pola adalah bentuk atau model yang bisa dipakai untuk membuat atau untuk menghasilkan suatu atau bagian dari sesuatu, khususnya jika sesuatu yang ditimbulkan cukup mempunyai suatu yang sejenis untuk pola dasar yang dapat ditunjukan atau terlihat, yang mana sesuatu itu dikatakan memerlukan pola. Sedangkan pembelajaran yaitu proses interaksi antara pendidik dan peserta didik di dalam kelas untuk saling bertukar informasi.

Adapun pengertian pola pembelajaran menurut para ahli di antaranya yaitu Menurut (Meyer, W.J., 1935:2) model dimaknakan sebagai suatu objek atau konsep yang digunakan untuk mempresentasikan suatu hal. Sesuatu yang nyata dan dikonversi untuk sebuah bentuk yang lebih konprehensif.

Menurut Joyce, (1992:4) model pembelajaran adalah suatu pola yang digunakan sebagai pedoman dalam perencanaan pembelajaran di kelas atau pembelajaran dalam tutorial dan untuk menentukan perangkat-perangkat pembelajaran termasuk di dalamnya buku-buku, film, komputer, kurikulum dan lain-lain.

Soekanto, dkk (dalam Nurulwati, 2000:10) model pembelajaran adalah kerangka konseptual yang melukiskan prosedur yang sistematis dalam mengorganisasikan pengalaman belajar untuk mencapai tujuan tertentu dan berfungsi sebagai pedoman bagi para 
perancang pembelajaran dan para pengajar dalam merencanakan aktivitas belajar mengajar.

Berdasarkan beberapa pengertian di atas dapat disimpulkan bahwa model pembelajaran adalah seperangkat prosedur yang sistematis sebagai perancang bagi para pengajar untuk mencapai tujuan belajar. Model pembelajaran dibagi menjadi dua, yaitu model pembelajaran yang berfokus pada guru ataupun yang berfokus pada siswa. Di mana model pembelajaran yang berfokus pada guru disebut Teacher Centered Learning (TCL) dan model pemblajaran yang berfokus pada siswa disebut Student Centered Learning (SCL).

\section{Teacher Centered Learning (TCL)}

Di Indonesia model pembelajaran yang digunakan masih bersifat konvensional, yang menjadikan siswa sebagai objek bukan subjek. Pada model ini, pendidik menjadi pusat peran dalam pencapaian hasil pembelajaran dan seakanakan menjadi satu-satunya sumber ilmu. Model pembelajaran ini pada umumnya membatasi setiap gerak ruang peserta didik untuk lebih aktif. Model pembelajaran ini menganggap semua siswa sama atau dalam dunia pendidikan dikenal dengan istilah seragamisasi, tanpa memikirkan potensi serta kebutuhan setiap peserta didik berbeda. Sistem pembelajaran seperti ini, disebut juga dengan sistem pembelajaran yang bersifat satu arah, karena yang ingin dicapai adalah bagaimana pendidik bisa mengajar dengan baik sehingga yang ada hanyalah transfer pengetahuan.

Model konvensional juga dikenal dengan model Teacher Centered Learning (TCL), dimana pada model ini guru atau pendidik sebagai seorang ahli menyampaikan ilmu pemgetahuan kepada peserta didik. Model pembelajaran seperti ini ternyata membuat peserta didik pasif karena hanya mendengarkan saat proses pembelajaran berlangsung sehingga kreativitas peserta didik kurang terpupuk atau bahkan cenderung tidak kreatif. Pada model TCL, pendidik lebih banyak melakukan kegiatan belajar-mengajar dengan bentuk ceramah (lecturing), sedangkan peserta didik pada saat proses pembelajaran berlangsung hanya mendengarkan ceramah, hanya sebatas memahami sambil membuat catatan, bagi yang merasa memerlukannya.

Modifikasi model pembelajaran CTL telah banyak dilakukan, antara lain mengkombinasikan lecturing dengan Tanya jawab dan pemberian tugas namun hasil yang dihasilkan masih diaggap belum optimal. Pola pembelajaan pendidik aktif dengan peserta didik pasif ini mempunyai efektivitas pembelajaran rendah, paling tidak bisa dilihat pada dua hal yakni pendidik sering hanya mengejar target waktu untuk menghabiskan materi pembelajaran dan pada saat-saat mendekati ujian, dimana aktivitas peserta dididk "berburu" catatan serta aktivitas belajar mereka mengalami kenaikan yang sangat signifikan, namun turun kembali secara signifikan pula setelah ujian selesai.

Dampak lain dari sistem pembelajaran TCL adalah guru atau pendidik kurang mengembangkan bahan ajar dan cenderung seadanya (menonton), terutama jika peserta didik cenderung pasif dan hanya sebagai penerima transfer ilmu. Pendidik mulai tampak tergerak untuk mengembangkan bahan ajar dengan banyak membaca jurnal atau download artikel hasil-hasil penilitian terbaru dari internet, jika peserta didiknya mempunyai kreaivitas tinggi, banyak bertanaya atau sering mengajak diskusi (Sudjana, 2005). 


\section{Student Centered Learning (SCL)}

Pendidikan pada era modern saat ini dituntut dengan suatu hal yang baru. Hal ini disebabkan karena dalam proses pembelajaran di sekolah secara khusus berbedabeda, bergantung dari materi, media, dan metode yang digunakan. Pembelajaran yang konvensional cenderung membuat siswa merasa jenuh mengikuti proses pembelajaran di kelas Melihat kondisi tersebut, maka diperlukan suatu pembelajaran yang menarik perhatian sisw dalam menyajikan suatu pembelajaran yang inovatif, maka diperlukan suatu media dan model yang sesuai dengan materi atau topik yang sedang dibahas. Untuk itu, guru sebagai ujung tombak yang mengarahkan siswa dalam mencapai tujuan pendidikan diharapkan dapat menggunakan media dan model pembelajaran yang inovatif ke dalam pembelajaran bahasa Indonesia.

SCL merupakan model pembelajaran yang berpusat pada siswa. Dalam model SCL, guru harus mampu melaksanakan perannya dengan baik yaitu tidak hanya sebgai pegajar, tetapi juga sebagai motivator, fasilitator, dan innovator. Guru tidak hanya dituntut untuk mengajar saja di depan kelas melainkan juga berperan membantu peserta didik untuk memecahkan masalah saat peserta didik mengalami kesulitan dalam proses pembelajaran. Natawijaya dalam Depdiknas (2005:31) menyebutkan bahwa belajar aktif adalah suatu sistem belajar mengajar yang menekankan keaktifan siswa secara fisik, mental intelektual dan emosional guna memperoleh hasil belajar berupa perpaduan antara aspek kognitif, afektif dan psikomotor.

Pada model pembelajaran $S C L$ peserta didik diuntut aktif mengerjakan tugas dan mendiskusikannya dengan guru/pendidik sebagai fasilitator. Dengan aktifnya siswa/peserta didik, maka kreativitas peserta didik akan terpupuk. Kondisi tersebut akan mendorong pendidik untuk selalu mengembangkan dan menyesuaikan materi pembelajaran dengan perkembangan Ilmu Pengetahuan dan Teknologi (IPTEK). Kemajuan teknologi informasi dan komunikasi yang menyediakan banyak cara untuk mendapatkan informasi sumber belajar, memberikan peluang untuk mengembangkan metode-metode pembelajaran baru secara optimal sehingga mendukung upaya mewujudkan kompetensi yang diharapkan. Kemajuan teknolgi juga memungkin siswa melakukan kegiatan belajar tidak hanya secara formal, tetapi belajar melalui berbagai media atau sumber. Dengan demikian guru/pendidik bukan lagi sebagai sumber belajar utama, melainkan sebagai mitra pembelajaran.

Pada model pembelajaran SCL, peserta dididk didorong untuk memiliki motivasi dalam diri sendiri, kemudian berupaya keras untuk mencapai kompetensi yang diinginkan. Hal ini bisa dilakukan dengan banyak berdiskusi, maka peserta didik berani mengemukakan pendapat, serta belajar memecahkan masalah yang dihadapi. SCL merupakan pendekatan dalam pembelajaran yang memfasilitasi pembelajar untuk terlibat dalam proses experiential learning. Bila pembelajar itu dapat dikategorikan ke dalam tipe-tipe activist, reflector, theorist, dan pragmatist, berarti pendekatan SCL tersebut merupakan metode yang dapat memfasilitasi pembelajar, dalam hal ini peserta didik sehingga secara langsung ataupun tidak dapat terlibat dalam proses pembelajaran. Model pembelajaran SCL, pada saat ini diusulkan menjadi model pembelajaran 
yang sebaiknya digunakan karena memiliki beberapa keunggulan yaitu:

1. Peserta didik akan dapat merasakan bahwa pembelajaran menjadi miliknya sendiri karena peserta didik diberi kesempatan yang luas untuk berpartisipasi.

2. Peserta didik memiliki motivasi yang kuat untuk mengikuti kegiatan pembelajaran.

3. Tumbuhnya suasana demokratis dalam pembelajaran sehingga akan terjadi dialog dan diskusi untuk saling belajarmembelajarkan diantara peserta didik.

4. Dapat menambahakan wawasan pikiran dan pengetahuan bagi pendidik Karena sesuatu yang dialami dan disampaikan peserta didik mungkin belum diketahui sebelumnya.

Keunggulan-keunggulan yang dimiliki model pembelajaran SCL tersebut akan mampu mendukung upaya ke arah pembelajaran yang efektif dan efisien (Harsono, 2009; Sudjana 2005).

\section{Perbedaan TCL dan SCL}

Pola pembelajaran yang terpusat pada dosen (Teacher Centered Learning/TCL) seperti yang dipraktikan pada saat ini sudah tidak memadai untuk mencapai tujuan pendidikan berbasis capaian pembelajaran. Berbagai alasan yang dapat dikemukakan antara lain adalah (i) perkembangan IPTEK dan seni yang sangat pesat dengan berbagai kemudahan untuk mengaksesnya merupakan materi pembelajaran yang sulit dapat dipenuhi oleh seorang pendidik, (ii) perubahan kompetensi kekaryaan yang berlangsung sangat cepat memerlukan materi dan proses pembelajaran yang lebih fleksibel, (iii) kebutuhan untuk mengakomodasi demokratisasi partisipatif dalam proses pembelajaran.
Oleh karena itu, pembelajaran ke depan di dorong menjadi berpusat pada peserta didik (Student Centered Learning/SCL) dengan memfokuskan pada capaian pembelajaran yang diharapkan. Berpusat pada peserta didik menyatakan bahwa capaian pembelajaran lulusan diraih melalui proses pembelajaran yang mengutamakan pengembangan kreativitas, kapasitas, kepribadian dan kebutuhan peserta didik, serta mengembangkan kemandirian dalam mencari dan menemukan pengetahuan. Peserta didik harus didorong untuk memliki motivasi dalam diri mereka sendiri, kemudian berupaya keras mencapai hasil pembelajaran yang diinginkan.

Perubahan pendekatan dalam pembelajaran dari TCL menjadi SCL adalaha perubahan paradigma, yaitu perubahan dalam cara memandang beberapa hal dalam pembelajaran, yakni; a) pengetahuan, dari pengetahuan yang dipandang sebagai sesuatu yang sudah jadi yang tinggal ditransfer dari dosen ke mahasiswa, menjadi pengetahuan dipandang sebagai hasil konstruksi atau hasil transformasi oleh pembelajar, b) belajar, belajar adalah menerima pengetahuan (pasif-reseptif) menjadi belajar adalah mencari dan mengkonstruksi pengetahuan, aktif dan spesifik caranya, c) pembelajaran, guru menyampaikan pengetahuan atau mengajar (ceramah dan kuliah) menjadi dosen berpartisipasi bersama peserta didik membentuk pengetahuan.

Dengan paradigma ini, maka tiga prinsip yang harus ada dalam pembelajaran SCL adalah (a) memandang pengetahuan sebagai satu hal yang belum lengkap, (b) memandang proses belajar sebagai proses untuk merekonstruksi dan mencari 
pengetahuan yang akan dipelajari;, serta (c) memandang proses pembelajaran bukan sebagai proses pengajaran (teaching) yang dapat dilakukan secara klasikal, dan bukan merupakan suatu proses untuk menjalankan sebuah instruksi baku yang telah dirancang. Proses pembelajaran adalah proses dimana pendidik menyediakan berbagai macam strategi dan metode pembelajaran dan paham akan pendekaan pembelajaran mahasiswanya untuk dapat mengembangkan potensi yang dimilikinya.

Perbedaan pendekatan pembelajaran yang berpusat pada pendidik (TCL) dan pembelajaran yang berpusat pada peserta didik (SCL) dapat dirinnci pada tabel berikut.

\begin{tabular}{|l|l|}
\hline \multicolumn{1}{|c|}{ TCL } & \multicolumn{1}{c|}{ SCL } \\
\hline $\begin{array}{l}\text { Pengetahuan } \\
\text { ditransfer dari } \\
\text { pendidik ke } \\
\text { peserta didik }\end{array}$ & $\begin{array}{l}\text { Peserta didik aktif } \\
\text { mengembangkan } \\
\text { pengetahuan dan } \\
\text { keterampilan yang } \\
\text { dipelajarainnya }\end{array}$ \\
\hline $\begin{array}{l}\text { Peserta didik } \\
\text { menerima } \\
\text { pengetahuan } \\
\text { secara pasif }\end{array}$ & $\begin{array}{l}\text { Peserta didik aktif } \\
\text { terlibat dalam } \\
\text { mengelola pengetahuan }\end{array}$ \\
\hline $\begin{array}{l}\text { Menekankan } \\
\text { pada } \\
\text { penguasaan } \\
\text { materi }\end{array}$ & $\begin{array}{l}\text { Tidak hanya } \\
\text { menekankan pada } \\
\text { penguasaan materi, } \\
\text { tetapi juga } \\
\text { mengembangkan } \\
\text { karakter peserta didik } \\
\text { (Life-Long Learning) }\end{array}$ \\
\hline $\begin{array}{l}\text { Bisa } \\
\text { memanfaatkan } \\
\text { media tunggal }\end{array}$ & $\begin{array}{l}\text { Memanfaatkan banyak } \\
\text { media (multimedia) }\end{array}$ \\
\hline $\begin{array}{l}\text { Fungsi } \\
\text { pendidik } \\
\text { sebagai } \\
\text { pemberi infor- } \\
\text { masi utama } \\
\text { dan evaluator }\end{array}$ & $\begin{array}{l}\text { Fungsi pendidik sebagai } \\
\text { fasilitator dan evaluasi } \\
\text { dilakukan bersama } \\
\text { dengan peserta didik }\end{array}$ \\
\hline
\end{tabular}

\begin{tabular}{|l|l|}
\hline Proses & Proses pembelajaran da \\
pembelajaran & asesmen dilakukan \\
dan penilaian & secara \\
dilakukan & berkesinambungan dan \\
secara terpisah & terintegrasi \\
\hline Menekankan & Penekanan pada proses \\
pada jawaban & pengembangan \\
yang benar & $\begin{array}{l}\text { pengetahuan. Kesalahan } \\
\text { dinilai dan dijadikan } \\
\text { sumber pembelajaran. }\end{array}$ \\
\hline
\end{tabular}

Ditambahkan pula oleh Jacobs dan Toh-Heng (2003) yang menjelaskan bahwa melalui metode TCL, penilaian difokuskan pada kekurangan yang dimiliki siswa dalam mencapai target prestasi tertentu dan menentukan cara untuk memperpendek jarak target dengan capaian prestasi riil siswa yang bersangkutan. Sementara itu di dalam metode SCL, siswa secara aktif dan mandiri berposes dalam penilaian diri sendiri dan melakukan evaluasi diri dengan panduan umpan balik dari guru. Di dalam setting TCL, motivasi siswa dalam belajar lebih banyak ekstrinsik karena bertumpu pada reward dan punisment yang diberikan oleh guru. Keadaan yang berbeda dijumapai pada kelas SCL dimana siswa didorong untuk belajar secara mandiri, bekerja dan belajar untuk menemukan banyak ide-ide, pengetahuan serta keterampilan baru berdasrkan motivasi intrinsik.

Penilitian menunjukkan bahwa motivasi dari dalam lebih efektif dibandingkan motivasi dari luar dalam upaya mencapai hasil belajar yang optimal. Motivasi dari dalam dapat dilakukan dengan membangkitkan perasaan ingin tahu, ingin mencoba, dan hasrat untuk maju dan belajar, sedangkan motivasi dari luar dapat dilakukan dengan memberikan ganjaran, yaitu hukuman dan pujian.

Namun demikian, keterlibatan guru dalam TCL justru menjadi kian penting. 
Pendidik diharapkan menjadi fasilitator dan mengembangkan komunikasi yang efektif dengan siswa selama pembelajaran berlangsung, terutama dalam mengarahkan siswa untuk mampu mengembangkan kemandirian, kerja sama, kemampuan memecahkan masalah dan pemahaman akan keunggulan diri sendiri terkait dengan tugas yang harus dilakukan (Geven \& Attard, 2012).

\section{Pembelajaran Student Centered Learning}

Menurut UU Nomor 20 tahun 2003 tentang Sistem Pendidikan Nasional dan Undang-undang Republik Indonesia Nomor 12 tahun 2012 tentang Pendidikan Tinggi, dinyatakan bahwa "pembelajaran adalah interaksi antara pendidik, peserta didik, dan sumber belajar, di dalam lingkungan belajar tertentu".

Berdasarkan pada pernyataan di atas, maka dalam mendeskripsikan setiap unsur yang terlibat dalam pembelajaran tersebut dapat ditengarai ciri pembelajaran yang berpusat pada peserta didik. Ciri metode pembelajaran SCL sesuai unsurnya dapat dapat diciri sebagai berikut: pendidik berperan sebagai fasilitator dan motivator; peserta didik, harus menunjukan kinerja, yang bersifat kreatif yang mengintegrasikan kemampuan kognitif, psikomotorik dan afeksi secara utuh; proses interaksinya, menitikberatkan pada "method of inquiry discovery"; sumber belajarnya, bersifat multidimensi, artinya bisa didapat dari mana saja; dan lingkungan belajarnya, harus terancang dan kontekstual.

Dalam proses pembelajaran SCL, guru masih memiliki peran yang penting dalam pelaksanaan SCL, yaitu:

1. Bertindak sebagai fasilitator dalam proses pembelajaran

2. Memahami capaian pembelajaran mata pelajaran yang perlu dikuasai peserta didik di akhir pembelajaran
3. Merancang strategi dan lingkungan pembelajaran yang dapat

4. Menyediakan beragam pengalaman belajar yang diperlukan peserta didik dalam rangka mencapai kompetensi yang dituntut dalam mata pelajaran

5. Membantu peserta didik mengakses informasi, menata dan memprosesnya untuk dimanfaatkan dalam memecahkan permaslahan hidup sehari-hari

6. Mengidentifikasi dan menentukan pola penilaian hasil belajar peserta didik yang relevan dengan capaian pembelajaran yang akan diukur.

Sementara itu, peran yang harus dilakukan oleh peserta didik dalam pembelajaran SCL adalah:

1. Memahami capaian pembelajaran pada mata pelajaran yang dipaparkan oleh guru atau pendidik

2. Menguasai strategi pembelajaran yang ditawrkan guru/pendidik

Belajar secara aktif (dengan cara mendengar, membaca, menulis, diskusi, dan terlibat dalam pemecahan masalah serta lebih penting lagi terlibat dalam kegiatan berpikir tingkat tinggi, seperti analisis, sintesis dan evaluasi), baik secara individu maupun berkelompok.

Proses pembelajaran melalui kegiatan kurikuler wajib dilakukan secara sistematis dan terstruktur melalui berbagai mata pelajaran dengan beban belajar yang terukur dan menggunakan metode pembelaj yang efektif sesuai dengan karakteristik mata pelajaran. Metode pembelajaran yang dapat dipilih untuk pelaksanaan pembelajaran antara lain:

\section{Small Grup Discussion}

Diskusi adalah salah satu elemen belajar secara aktif dan merupakan bagian dari banyak model pembelajaran SCL yang lain, seperti CL, CbL, PBL, dan lain-lain. 
Peserta didik diminta membuat kelompok kecil (5 sampai 10 orang) untuk mendiskusikan bahan yang diberikan oleh guru atau bahan yang diperoleh sendiri oleh anggota kelompok tersebut. Dengan aktivitas kelompok kecil, peserta didik akan belajar; (a) Menjadi pendengar yang baik, (b) Bekerja sama untuk tugas bersama, (c) Memberikan dan menerima umpan balik yang konstruktif (d) Menghormati perbedaan pendapat, (e) Mendukung pendapat dengan bukti (f) Menghargai sudut pandang yang bervariasi (gender, budaya dan lain-lain).

Adapun aktivitas diskusi kelompok kecil dapat berupa:

1. Membangkitkan ide

2. Menyimpulkan poin penting

3. Mengakses tingkat skill dan pengetahuan

4. Mengkaji kembali topic di kelas sebelumnya

5. Menelaah latihan, kuis, tugas menulis

6. Memproses outcome pembelajaran pada akhir kelas

7. Memberi komentar tentang jalannya kelas

8. Membandingkan teori, isu dan interpretasi

9. Menyelesikan masalah dan

10. Brainstroming

\section{Simulasi/Demonstrasi}

Simulasi adalah model yang membawa situasi yang mirip dengan sesungguhnya ke dalam kelas. Simulasi dapat berbentuk (1) permainan peran (role playing). (2) simulation exercises and simulation games (3) model komputer. Simulasi dapat mengubah cara pandang (mindset) peserta didik, dengan jalan: (1) mempraktikan kemampuan umum (missal komunikasi verbal dan nonverbal); (2) mempraktikan kemampuan khusus; (3) mempraktikan kemampuan tim; (4) mengembangkan kemampuan menyelesaikan masalah (problem solving); menggunakan kemampuan sintesis; dan (6) mengembangkan kemampuan empati.

\section{Discovery Learning}

DL adalah metode metode belajar yang sering difokuskan pada pemanfaatan informasi yang tersedia, baik yang diberikan guru maupun yang dicari sendiri oleh peserta didik, untuk membangun pengetahuan dengan cara belajar mandiri.

\section{Self Directed Learning}

SDL adalah proses belajar yang dilakukan atas inisiatif individu peserta didik sendiri. Dalam hal ini, perencanaan, pelaksanaan, dn penilaian terhadap pengalaman belajar yang telah dijalani, dilakukan semuanya oleh individu yang bersangkutan. Sementara guru hanya bertindak sebagai fasilitator, yang memberi arahan, bimbingan, dan konfirmasi terhadap kemajuan belajar yang telah dilakukan individu peserta didik tersebut.

\section{Cooperative Learning (CL)}

CL adalah metode belajar berkelompok yang dirancang oleh pendidik untuk memecahkan suatu masalah/kasus atau mengerjakan suatu tugas. Kelompok ini terdiri atas beberapa orang peserta didik yang memiliki kemampuan yang beragam.

\section{Collaborative Learning (CBL)}

$\mathrm{CbL}$ adalah metode belajar yang menitikberatkan pada kerja sama antar peserta didik yang didasarkan pada konsensus yang dibangun sendiri oleh anggota kelompok. Masalah/ tugas/ kasus memang berasal dari pendidik dan bersifat open ended, tetapi pembentukan kelompok yang didasrkan pada minat, prosedur 
dengan bagaimana hasil diskusi/ kerja kelompok, sampai dengan bagaimana hasil diskusi/ kerja kelompok ingin dinilai oleh pendidik, semuanya ditentukan melalui konsensus bersama antar anggota kelompok.

\section{Contextual Instruction (CI)}

CI adalah konsep belajar yang membantu pendidik mengaitkan isi mata pelajaran dengan situasi nyata dalam kehidupan sehari-hari dan memotivasi mahasiswa untuk membuat keterhubungan antara pengetahuan dan aplikasinya dalam kehidupan sehari-hari sebagai anggota masyarakat, pelaku kerja profesional atau manajerial, enterpreneur maupun investor.

\section{Project-Basic Learning}

PjBL adalah metode lbelajar yang sistematis, yang melibatkan peserta didik dalam belajar pengetahuan dan keterampilan melalui proses prncarian/ penggalian (inquiry) yang panjang dan terstruktur terhadap pertanyaan otentik dan kompleks serta tugas dan produk yang dirancang dengan sangat hati-hati.

\section{Problem-Based Learning/Inquiry (PBL/I)}

PBL/I aalah belajar dengan memanfaatkan maslah dan peserta didik harus melakukan pencarian/penggalian informasi (inquiry) untuk dapat memecahkan masalah tersebut. Pada umumnya, terdapat empat langkah yang perlu dilakukan peserta didik dalam PBL/I, yaitu: (1) menerima masalah yang relevan dengan salah satu/beberapa kompetensi yang dituntut mata pelajaran dari gurunya; (2) melakukan pencarian data dan informasi yang relevan untuk memecahkan masalah; (3) menata data dan mengaitkan data dengan masalah; (4) menganilisis strategi pemecahan masalah PBL/I adalah belajar dengan memanfaatkan masaalah dan peserta didik harus melakukan pencarian/penggalian informasi (inquiry) untuk daapat memecahkan masalah tersebut.

\section{PENUTUP}

Pola pembelajaran merupakan hal penting yang harus diperhatikan dalam proses belajar mengajar. Karena dengan pola pembelajaran yang sesuai dapat menentukan keberhasilan belajar jangka panjang bagi siswa. Oleh karenanya seorang pendidik harus kreatif dalam memilih serta menerapkan model/pola pembelajaran yang digunakan sebagai pedoman dalam perencanaan pembelajaran secara sistematis dalam kelas agar teciptanya pengalaman belajar yang baik bagi siswa, sehingga dalam menerima pembelajaran, siswa mampu berpikir secara rasional, logis, dan kritis serta sistematis.

Pola pembelajaran harus disesuaikan dengan perkembangan kurikulum yang diterapkan. Mengapa diperlukan perubahan kurikulum sebelumnya menjadi kurikulum berbasis kompetensi karena tantangan pendidikan pada era globalisasi adalah menghasilkan Sumber Daya Manusia (SDM) yang mampu berperan secara global.

Dewasa ini perkembangan Ilmu Pengetahuan dan Teknologi (IPTEK) semakin canggih dan luas, oleh karenanya pola pembelajaran juga harus mengalami perubahan dari Teacher Centered Learnning (TCL) menjadi Student Centered Learning ( $S C L$ ) dimana guru tidak hanya menjadi sentral dalam memberikan informasi dalam pembelajaran namun sebagai fasilitator dan motivator dan siswa harus menunjukkan kinerja, yang bersifat kreatif yang menintegrasikan kemampuan 
kognitif, psikomotorik dan afeksi secara utuh. Dan proses interaksinya, menitikberatkan pada method of inquiry and discovery. Sumber belajarnya bersifat multidimensi serta lingkungan belajar yang terancang dan kontekstual. Tujuan dari pola pembelajaran merupakan proses perubahan cara perpikir pada siswa sebagai hasil dari pengalaman dalam berinteraksi dengan lingkungannya.

\section{DAFTAR PUSTAKA}

Amhari, Ahmad. 2014. Model Pembelajaran Teacher Centerdan Studen Center, (Online), (http://amdayhary.blogspot.com/, Diakses pada 23 November 2018).

Antika, Reza Rindy. 2014. Proses Pembelajaran Berbasis Student Centered Learning (Studi Deskriptif di Sekolah Menengah Pertama Islam Baitul 'Izzah. Artikel BioKultur, 3(1), halaman 252.

Jamaati, Suprihatin. 2015. Peningkatan Motivasi Belajar Bahasa Indonesia Tentang Membaca Intensif Melalui Metode Diskusi pada Siswa Kelas IV SD Negeri Sriwedari 01 Semester II Tahun Pelajaran 2014/2015.

Khodijah, Nyayu. 2016. Psikologi Pendidikan. Jakarta: Rajawali Pers

Kurdi, Fauziah Nuraini. 2009. Penerapan Student Centered Learning dari Teacher Centered Learning Mata Ajar Ilmu Kesehatan pada Program Studi Penjaskes. Forum Kependidikan, 28(2), halaman 109.

Mansyur, Umar. 2013. Evaluasi Kompetensi Pedagogik Guru Bahasa Indonesia SMP Peserta MGMP dan yang Bukan Peserta MGMP di Kabupaten Pinrang. Thesis. Makassar: Universitas Negeri Makassar

Mansyur, Umar. 2016. Inovasi Pembelajaran Bahasa Indonesia melalui Pendekatan Proses. Retorika: Jurnal Bahasa, Sastra, dan Pengajarannya, 9(2), 158-163. https://doi.org/10.26858/retorika.v9i2.3806.

Mansyur, Umar. 2018. Pembelajaran Inovatif Bahasa Indonesia di Sekolah Dasar. INA-Rxiv. https://doi.org/10.31227/osf.io/fyr8g.

Mulyadi, Seto, Basuki, Heru, M, A. \& Rahardjo, Wahyu. 2016. Psikologi Pendidikan dengan Pendekatan Teori-teori Baru dalam Psikologi. Depok: PT RajaGrafindo Persada.

Valmey, Dyas. 2016. Problematika dalam Metode Pembelajaran dan Solusi Pemecahannya, (Online), (http://dyasvalmey.blogspot.com/, Diakses pada 23 November 2018). 